\title{
References
}

1. Colombia, M et al. Quality assurance in drug information centres. Online CDROM Review, 17 (5), 1993 p279 - 284.

2. Nixon, J. Factline '91: an evaluation of a drugs information campaign in Brighton. Brighton: University of Brighton. (Drugs Prevention Initiative), Occasional Paper,1992.

3. Murphy, Sand Smith, C. Crutches, confetti or useful tools? Professionals views and the use of health education leaflets. Health Education Research, 8 (2), 1993, p 205 - 215.

\section{Developing the flexible library and information workforce}

\author{
ANNE GOULDING and EVELYN KERSLAKE \\ Department of Information and Library Studies, \\ Loughborough University
}

\section{Introduction}

Flexibility is a vaguely defined media buzzword connoting the progressive, forward-looking workplace. Employers report that increased labour market flexibility has made them more cost-effective, efficient, better able to deal with customer and employee demands and the implementation of new technology. But what is happening to those workers who make up the flexible workforce? For a while in the 1980 s it seemed that flexibility could do no wrong; now, however, the shortcomings of flexible labour markets are becoming more apparent.

Recently, concerns abut the longer term implications of a flexible workforce have been raised by organizations as varied as the CBI and NIACE (the National Institute for Continuing Adult Education), particularly in relation to impact of the flexible workforce on the overall skills profile of the labour market. Recent work suggests that 38.2 per cent of all workers in the UK are flexible workers so, with such a significant proportion of the labour market in flexible employment, where does responsibility lie for providing and paying for their training and development?

Currently, employers seem willing to invest in training and development primarily for their permanent, fulltime workers. ${ }^{1}$ However, continuing to ignore the training needs of flexible workers could endanger any benefits gained with increased flexibility. Failure to train flexible workers might perhaps contravene sex discrimination legislation too. After the House of Lords decision, in late 1994, that discrimination against part-time workers was discrimination against women, as well are the great majority of part-time workers, a similar interpretation could apply to the training of flexible workers, who are also mostly women.

\section{Flexibility and library and information services}

Library and information services are no strangers to flexible working patterns - the widespread use of extended opening hours with varying workloads ensures this. A study of UK library and information services funded by Loughborough University's School of Education and Humanities earlier this year (1995) demonstrated the significant incidence of flexible workers in this area. The study involved public, academic and special libraries in a postal questionnaire survey which had a response rate of 57 per cent. It found that of 38,000 workers in 475 organizations responding to the survey, 40 per cent were flexible workers, and that flexible working patterns were found in all library types and among professional and support staff. Flexible workers were defined as those workers who were on permanent part-time, temporary part-time, job share, annual hours, term time only, temporary full-time and homeworking contracts. 
The largest group of flexible workers in this survey were permanent part-time workers, followed by temporary part-time and job share workers. While there was evidence of some services using newer work patterns, such as home-working and annual hours contracts, these were mostly seen as experiments, although they were often viewed favourably. Those managers who had introduced annual hours contracts on a trial basis were particularly strong advocates for the wider implementation of these working patterns, especially in customer service/contact areas.

\section{Developing flexible library and information workers}

In view of the significant proportion of flexible library and information workers, a consideration of the training and development issues from a total quality management perspective is necessary, and the high incidence of women flexible workers in library and information services makes an investigation of the inherent equal opportunities implications imperative. Both perspectives are being explored in a one year project (September 1995-September 1996) at Loughborough University, funded by the British Library Research and Development Department.

\section{Aims and objectives}

Although there have been Library Training Guides on both the management of training provision and training and development for women, aspects of equal opportunities and training for the UK's flexible library and information workforce have scarcely been explored. The aim of the project, therefore, is to investigate whether employers in the library and information sector in the UK differentiate between flexible and mainstream workers in their training programmes, and, if so, how, and on what grounds.

The project will explore the attitudes of professional and support flexible workers towards workplace training, specifically addressing what training is currently provided; what training flexible workers would like and how they would prefer that training to be delivered; and what, if any, barriers to training flexible workers perceive. The implications raised here will be investigated in terms of the quality of service provided to the library user; equal opportunities practice; and staff turnover rates and workforce planning.

\section{Methodology}

\section{i) Literature review}

Literature from the fields of management and organizational psychology, sociology of work, women's studies and, primarily, library and information science, will be reviewed to identify issues surrounding employers' motivation to train, the training of flexible workers, training and equal opportunities, service quality and workforce planning.

\section{ii) Mail questionnaire}

Drawing on the issues identified in (i) above, a questionnaire examining the issues for organizational training implied in the use of flexible workers will be sent to public, academic and special libraries.

\section{iii) $\underline{\text { Case studies }}$}

From the results of the questionnaire survey, a selection of 'critical' case studies will be carried out. The case studies will involve, firstly, individual interviews with members of the organization's senior management team, and secondly, group interviews with flexible workers to explore their perspective on training.

\section{Dissemination of results}

Practical guidelines for managers suggesting how they might develop training policies to maximize the potential of their flexible workforce and avoid discriminating against them will be included in a final 
research report which will also analyze data gathered in the course of the study. Journal and conference papers are also planned.

\section{References}

1. Flexible labour markets. Who pays for training? London: BBI, 1994.

2. Watson, G. The flexible workforce and patterns of working hours in the UK. Employment Gazette. July. 1994

3. Goulding, A. and Kerslake, E. A firm commitment to flexibility. Library Association Record. November. 1995

4. Morris, B. Training and development for women. London: Library Association, 1993

5. Whetherley, J. Management of training and staff development. London: Library Association, 1994 